\title{
PENGARUH PENAMBAHAN AROMA VANILI TERHADAP KARAKTERISTIK BERAS ANALOG BERBAHAN BAKU TEPUNG UBI KAYU YANG DIPERKAYA DENGAN PROTEIN IKAN LELE
}

\section{THE EFFECT OF VANILLA ADDITION ON CHARACTERISTIC OF ANALOG RICE MADE FROM CASSAVA FLOUR ENRICHED WITH CATFISH PROTEIN}

\author{
Junarli $^{1}$, Tamrin ${ }^{2}$, Siti Suharyatun ${ }^{2}$ \\ ${ }^{1}$ Mahasiswa Teknik Pertanian, Fakultas Pertanian, Universitas Lampung \\ ${ }^{2}$ Dosen Jurusan Teknik Pertanian, Fakultas Pertanian, Universitas Lampung \\ ${ }^{\square}$ komunikasi penulis, e-mail : junarli2326@gmail.com \\ Naskah ini diterima pada 25 November 2017; revisi pada 31 November 2017; \\ disetujui untuk dipublikasikan pada 26 Desember 2017
}

\begin{abstract}
Rice consumption in Indonesia is very high because it is the main source of carbohydrates in the diet of Indonesian people. As a result dependence on rice production is very high. The level of community dependence on the main source of carbohydrates needs to be reduced because it will affect on food security. One approach to reduce the level of dependence on rice is through food diversification which is producing an analog rice. This study aims to study the effect of vanilla addition in analog rice made from cassava flour that was enriched with catfish protein. The main materials and tools used are cassava flour, catfish and vanilla powder. This research used factorial of random experimental design. The first factor was the composition of catfish flour (5\%, 7,5\%, and 10\%) and second factor of vanilla aroma concentration ( $5 \mathrm{~g}, 7 \mathrm{~g}$ and $10 \mathrm{~g}$ ) with 2 replications. Parameters measured including of density, absorption, hardness, moisture content, color, and sensory test. The results showed that the analog rice had density characteristics ranging from $0.63 \%-0.71 \%$, absorption $85.2 \%-107.4 \%$, hardness 7.01 - 9.19, and water content $7.10 \%-11.52 \%$. The addition of vanilla flavour had no effect on the characteristics of analog rice. The most preferred analog rice panel was analog rice that had 5\% catfish flour and vanilla $10 \mathrm{gr} / \mathrm{kg}$.
\end{abstract}

Keywords: cassava flour, catfish protein, and vanilla flavour.

\begin{abstract}
ABSTRAK
Konsumsi beras di Indonesia sangat tinggi karena beras merupakan sumber karbohidrat utama dalam pola makan sebagian besar masyarakat Indonesia. Akibatnya ketergantungan terhadap produksi beras sangat tinggi. Tingkat ketergantungan masyarakat terhadap satu sumber karbohidrat saja perlu dikurangi karena akan berdampak terhadap ketahanan pangan. Salah satu pendekatan untuk mengurangi tingkat ketergantungan terhadap beras adalah melalui diversifikasi pangan, yaitu dengan pembuatan beras analog. Penelitian ini bertujuan mempelajari pengaruh penambahan vanili pada beras analog berbahan baku tepung ubi kayu yang diperkaya dengan protein ikan lele terhadap aroma yang dihasilkan. Bahan dan alat utama yang digunakan adalah tepung ubi kayu, ikan lele dan vanili bubuk. Penelitian ini menggunakan rancangan Faktorial. Faktor pertama adalah penambahan tepung ikan lele (5\%, 7,5\%, dan 10\%) dan faktor kedua penambahan konsentrasi aroma vanili ( 5 g, $7 \mathrm{~g}$ dan $10 \mathrm{~g}$ ) dengan 2 kali ulangan. Parameter yang diukur : densitas, daya serap, kekerasan, kadar air, warna, dan uji sensorik. Hasil penelitian menunjukkan bahwa beras analog yang dihasilkan memiliki karakteristik densitas berkisar 0,63 \% $0,71 \%$, daya serap 85,2 \% - 107,4 \%, kekerasan 7,01 - 9,19, dan kadar air 7,10 \% - 11,52 \%. Penambahan aroma vanili tidak berpengaruh terhadap karakteristik beras analog. Beras analog yang paling disukai panelis adalah beras dengan penambahan tepung ikan lele $5 \%$ dan vanili $10 \mathrm{gr} / \mathrm{kg}$.
\end{abstract}

Kata Kunci : Tepung ubi kayu, tepung ikan lele, dan aroma vanili. 


\section{PENDAHULUAN}

Beras telah lama menjadi komoditas pangan yang paling pokok bagi sebagian besar masyarakat Indonesia (Kosasih 2015). Diversifikasi pangan merupakan upaya menganekaragamkan jenis pangan yang tidak hanya tergantung pada satu jenis pangan, akan tetapi memiliki beragam pilihan (alternatif) terhadap berbagai bahan pangan. Diversifikasi pangan dapat mengurangi masalah ketergantungan beras, salah satu wujudnya adalah melalui pembuatan beras analog. Beras analog merupakan tiruan dari beras yang terbuat dari bahan-bahan seperti, umbi-umbian dan serealia yang bentuk maupun komposisi gizinya mirip dengan beras. Singkong atau ubi kayu merupakan salah satu sumber karbohidrat di Indonesia peringkat ketiga setelah padi dan jagung. Singkong juga merupakan bahan baku yang sangat berpotensi untuk dijadikan tepung (Prabawati, dkk., 2011). Setelah menjadi tepung, singkong mengandung kadar air 10-12\%, kadar lemak 0,8-1,0\%, abu 0,6-0,8\%, protein 1,2-1,8\%, karbohidrat $85-88 \%$ serta kadar amilosa 20-31\% (Widowati, 2009).

Penggunaan tepung singkong sebagai bahan baku pembuatan beras analog memiliki kandungan gizi (khususnya protein) lebih rendah dibandingkan dengan beras. Oleh karena itu, perlu penambahan bahan untuk meningkatkan kandungan gizi dari dari tepung singkong. Dilihat dari sisi lain Indonesia kaya akan sumber protein hewani, salah satunya yaitu ikan lele. Penambahan ikan lele sebagai bahan tambahan dalam pembuatan beras analog memiliki bau amis yang kuat, dengan adanya kandungan protein yang terdapat pada ikan lele. Maka, dalam pembuatan tepung ikan lele perlu ditambahkan zat aditif sebagai penyedap aroma makanan untuk mengurangi bau amis. Salah satu zat aditif alami yang sering digunakan untuk penyedap makanan adalah vanili. Sehingga perlu dikaji pengaruh penambahan aroma vanili terhadap karakter beras analog berbahan baku tepung ubi kayu yang diperkaya dengan protein ikan lele.

\section{METODOLOGI PENELITIAN}

Penelitian ini dilaksanakan pada bulan November 2016 sampai Maret 2017, bertempat di Laboratorium Daya Alat dan Mesin Pertanian, dan Laboratorium Rekayasa Bioproses dan Pasca Panen Jurusan Teknik Pertanian Universitas Lampung. Alat yang digunakan dalam penelitian ini adalah Chopper chip ubi kayu, Rheometer, Ayakan manual, Timbangan manual, Timbangan digital, Cawan, Nampan dan tampah, Stopwatch, Oven, Mesin penepungan (disk miil), Granulator, Mesin pengukus. Sementara bahan yang digunakan dalam penelitian ini adalah tepung singkong (ubi kayu), tepung ikan lele, vanili, dan air.

Penelitian ini menggunakan rancangan Faktorial dengan 2 faktor, yaitu penambahan tepung ikan lele, terdiri dari 3 taraf yaitu X1 = 5\%, X2 = 7,5\%, $\mathrm{X} 3=10 \%$. Faktor kedua adalah penambahan konsentrasi aroma vanili, terdiri dari tiga taraf yaitu $\mathrm{Y} 1=5 \mathrm{~g}$ vanili, $\mathrm{Y} 2=7 \mathrm{~g}$ vanili, $\mathrm{Y} 3=10 \mathrm{~g}$ vanili. Penelitian dilakukan dengan 2 kali ulangan. Proses pembuatan beras analog dilakukan dengan pencampuran tepung singkong dan tepung ikan lele dengan perbandingan komposisi Sesuai perlakuan. Pembuatan granula dengan menggunakan mesin granulator yang dilakukan selama \pm 10 menit. Setelah menjadi granul (butiran), beras analog dijemur dibawah sinar matahari. Selanjutnya beras analog dikukus dengan penambahan aroma vanili sesuai perlakuan. Granul (butiran) beras analog setelah pengukusan dikeringkan dibawah sinar matahari hingga kering. Selanjutnya dianalisis serta uji karakteristik setelah dilakukan pemasakan kembali.

\section{HASIL DAN PEMBAHASAN}

\subsection{Densitas (Kerapatan Curah)}

Dari hasil pengukuran pada setiap perlakuan yang telah dilakukan, penambahan aroma vanili kedalam pembuatan beras analog berbahan baku tepung ubi kayu yang diperkaya dengan protein daging ikan lele tidak mempengaruhi nilai densitas yang dihasilkan, seperti yang terlihat dalam grafik pada Gambar 1. Hal ini diperkuatkan dengan hasil analisis sidik ragam.

Berdasarkan analisis sidik ragam pada taraf uji (alpha $>0.05$ ), penambahan aroma vanili terhadap karakter beras analog berbahan baku tepung ubi kayu yang diperkaya dengan protein ikan lele tidak berpengaruh terhadap densitas 


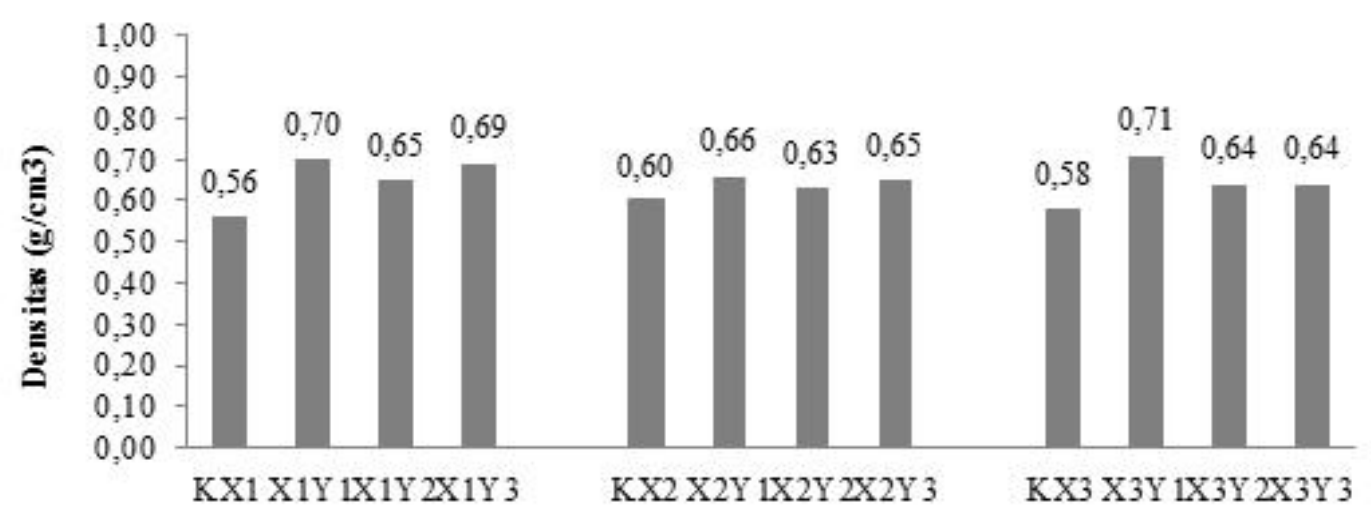

Perlakuan

Gambar 1. Densitas pada masing-masing perlakuan

Keterangan: $\mathrm{K}=$ Kontrol; $\mathrm{X} 1=5 \%$ tepung ikan lele; $\mathrm{X} 2=7,5 \%$ tepung ikan lele; $\mathrm{X} 3=$ $10 \%$ tepung ikan lele; $\mathrm{Y} 1$ = $5 \mathrm{~g}$ vanili; $\mathrm{Y} 2$ = $7 \mathrm{~g}$ vanili; $\mathrm{Y} 3=10 \mathrm{~g}$ vanili

atau kerapatan curah yang dihasilkan. Perbedaan presentase penambahan tepung ikan lele dan aroma vanili serta interaksi antar keduanya tidak berpengaruh terhadap densitas atau kerapatan curah dengan nilai á $>0.05$. Hal ini diduga diameter butiran beras analog seragam sehingga tidak terdapat perbedaan densitas secara signifikan. Hasil analisis sidik ragam terhadap densitas dapat dilihat pada Tabel 1.

\subsection{Daya Serap Air}

Daya serap air merupakan kemampuan produk untuk menyerap air secara maksimal (Dewi, 2008). Berdasarkan penelitian daya serap air setiap perlakuan disajikan dalam bentuk grafik seperti pada Gambar 2. Daya serap air tertinggi ada pada perlakuan X2Y1 (7,5\% tepung ikan lele dan $5 \mathrm{~g}$ vanili bubuk) sebesar 107,4 \% dan daya serap terendah pada X2Y2 (7,5 \% tepung ikan lele dan 7 g vanili bubuk).

Tabel 1. analisis sidik ragam terhadap densitas.

\begin{tabular}{lcrrrr}
\hline Sumber & $\begin{array}{l}\text { Derajat } \\
\text { Keragaman }\end{array}$ & Tebas I SS & $\begin{array}{l}\text { Jumlah } \\
\text { Kuadrat }\end{array}$ & Nilai F & \multirow{2}{*}{$\operatorname{Pr}>$ F } \\
\hline Tepung ikan lele & 2 & 0.0027 & 0.00135 & 0.75 & 0.4977 \\
Vanili bubuk & 2 & 0.00663 & 0.00332 & 1.85 & 0.2117 \\
Interaksi & 4 & 0.00297 & 0.00074 & 0.41 & 0.7943 \\
\hline
\end{tabular}

Ket : Jika nilai $\mathrm{Pr}>\mathrm{F}$ lebih besar dari alpha $=0.05$ maka perlakuan tidak berpengaruh, sebaliknya jika nilai $\operatorname{Pr}<$ F lebih kecil dari alpha= 0.05 maka perlakuan berpengaruh.

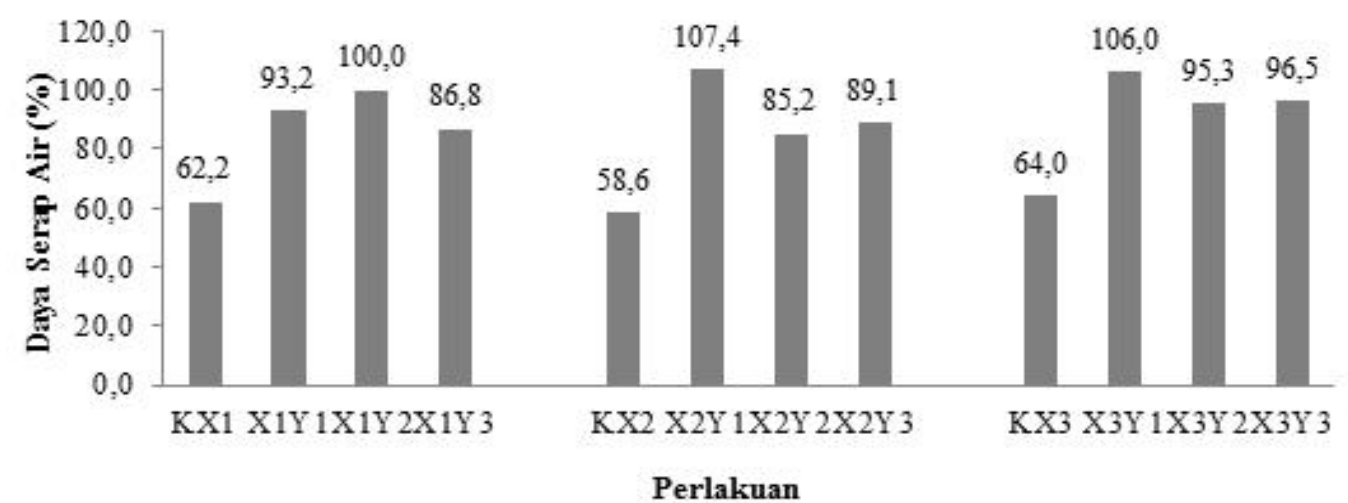

Gambar 2. Densitas pada masing-masing perlakuan

Keterangan: $\mathrm{K}=$ Kontrol; $\mathrm{X} 1=5 \%$ tepung ikan lele; $\mathrm{X} 2=7,5 \%$ tepung ikan lele; $\mathrm{X} 3=$ $10 \%$ tepung ikan lele; $\mathrm{Y} 1=5 \mathrm{~g}$ vanili; $\mathrm{Y} 2=7 \mathrm{~g}$ vanili; $\mathrm{Y} 3=10 \mathrm{~g}$ vanili 
Berdasarkan analisis sidik ragam alpha $>0.05$ yang telah dilakukan, dalam pembuatan beras analog berbahan baku tepung ubi kayu yang diperkaya protein ikan lele dengan penambahan aroma vanili diketahui daya serap air tidak dipengaruhi oleh penambahan tepung ikan lele dan vanili bubuk yang dapat dilihat pada Tabel 2 sehingga tidak perlu dilakukan uji lanjut duncan. kekompakan ikatan butir pati pada campuran kedua pati yang disebabkan tidak adanya rongga udara di antara granula pati. Kekerasan beras analog setiap perlakuan ditambah tepung ikan lele yang diperkaya aroma vanili tidak jauh berbeda dengan nilai kontrol beras analog tanpa penambahan aroma vanili, dapat dilihat pada Gambar 3.

Tabel 2. Analisis sidik ragam terhadap daya serap

\begin{tabular}{lrrrrr}
\hline Sumber & $\begin{array}{l}\text { Derajat } \\
\text { Keragaman }\end{array}$ & Tebas & Tipe I SS & $\begin{array}{l}\text { Jumlah } \\
\text { Kuadrat }\end{array}$ & \multicolumn{2}{c}{ Nilai F } & \multirow{2}{*}{ Pr $>$ F } \\
\hline Tepung ikan lele & 2 & 129.8 & 64.92 & 0.49 & 0.627 \\
Vanili bubuk & 2 & 426.4 & 213.2 & 1.61 & 0.252 \\
Interaksi & 4 & 450.2 & 112.5 & 0.85 & 0.527 \\
\hline
\end{tabular}

Ket : Jika nilai $\mathrm{Pr}>\mathrm{F}$ lebih besar dari alpha $=0.05$ maka perlakuan tidak berpengaruh, sebaliknya jika nilai $\operatorname{Pr}<$ F lebih kecil dari alpha= 0.05 maka perlakuan berpengaruh.

\subsection{Kekerasan}

Menurut Fitriyanto (2013), Amilosa merupakan faktor penting yang mempengaruhi kekuatan gel pati yang menyebabkan struktur beras analog menjadi keras. Amilosa dapat membentuk struktur kristal karena struktur rantai polimer yang dimiliki amilosa sederhana sehingga dapat terjadi interaksi molekuler yang kuat. Selain amilosa, penyebab kekerasan beras buatan yaitu
Berdasarkan analisis sidik ragam á $>0.05$, dalam pembuatan beras analog berbahan baku tepung singkong yang diperkaya dengan daging ikan lele dan penambahan aroma vanili kekerasan tidak berpengaruh nyata, hal ini dikarenakan ukuran setiap butiran beras analog hampir seragam pada setiap perlakuan tidak jauh berbeda, seperti pada Tabel 3.

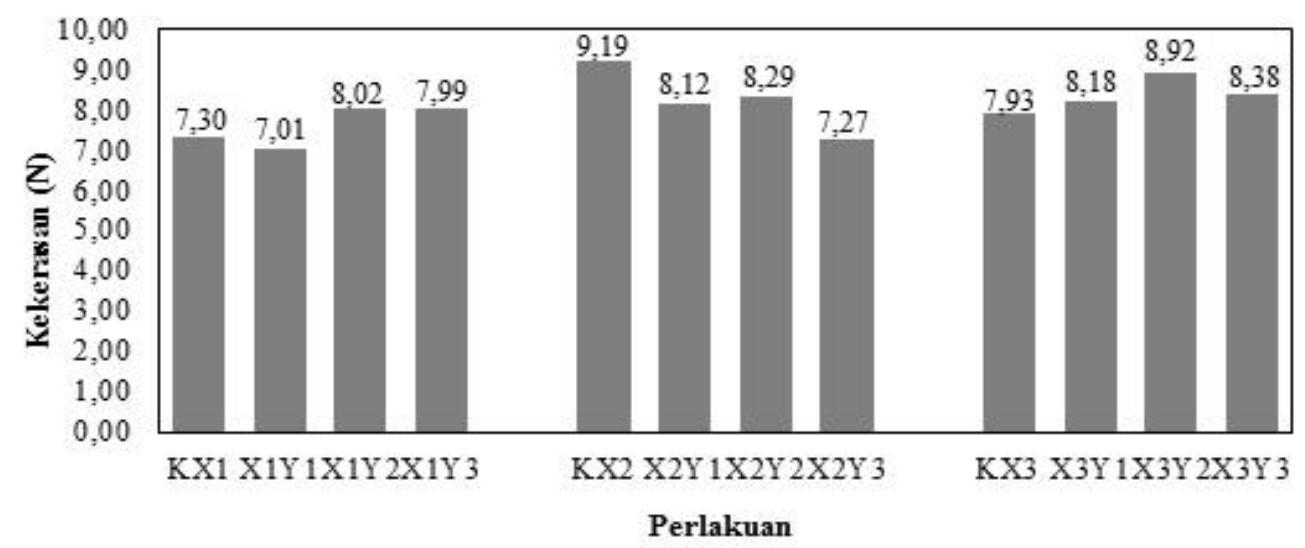

Gambar 3. Kekerasan pada masing-masing perlakuan

Keterangan: $\mathrm{K}=$ Kontrol; $\mathrm{X} 1=5 \%$ tepung ikan lele; $\mathrm{X} 2=7,5 \%$ tepung ikan lele; $\mathrm{X} 3=$ $10 \%$ tepung ikan lele; $\mathrm{Y} 1$ = $5 \mathrm{~g}$ vanili; $\mathrm{Y} 2$ = $7 \mathrm{~g}$ vanili; $\mathrm{Y} 3=10 \mathrm{~g}$ vanili

Tabel 3. Analisis sidik ragam terhadap kekerasan

\begin{tabular}{llrcrrr}
\hline $\begin{array}{l}\text { Sumber } \\
\text { Keragaman }\end{array}$ & $\begin{array}{l}\text { Dearajat } \\
\text { Bebas }\end{array}$ & Tipe I SS & $\begin{array}{l}\text { Jumlah } \\
\text { Kuadrat }\end{array}$ & Nilai F & Pr $>$ F \\
\hline Tepung ikan lele & 2 & 2.1409 & 1.07045 & 0.3 & 0.7513 \\
Vanili bubuk & 2 & 1.39243 & 0.69622 & 0.19 & 0.8286 \\
Interaksi & 4 & 1.70857 & 0.42714 & 0.12 & 0.9728 \\
\hline
\end{tabular}

Ket : Jika nilai $\mathrm{Pr}>\mathrm{F}$ lebih besar dari alpha $=0.05$ maka perlakuan tidak berpengaruh, sebaliknya jika nilai $\operatorname{Pr}<\mathrm{F}$ lebih kecil dari alpha= 0.05 maka perlakuan berpengaruh. 


\subsection{Kadar Air}

Pada penelitian ini nilai tertinggi untuk kadar air terdapat pada perlakuan X1Y3 (5\% tepung ikan lele dan $10 \mathrm{~g}$ vanili bubuk) sebesar 11,52 \%. Peningkatan kadar air pada perlakuan X1Y3 di pengaruhi oleh lamanya pengeringan beras analog setelah pengukusan Kadar air yang diperoleh tidak jauh berbeda dengan yang didapatkan pada penelitian sebelumnya milik (Franciska dkk, 2015), berkisar antara 11,87 13,19\%. Kadar air yang didapat sudah mendekati kadar air maksimum beras giling yaitu 14\% (BPS, 2013) dalam (Franciska dkk, 2015). Kadar air terendah terdapat pada X3Y1 (10\% tepung ikan lele dan $5 \mathrm{~g}$ vanili) sebesar 7,10\%. Gambar 4 adalah grafik kadar air yang diperoleh dari masing-masing perlakuan pada pembuatan beras analog dari hasil pengukuran.

\subsection{Warna}

Uji warna dalam penelitian ini menggunakan tabel warna flat design color chart yang dilakukan dengan cara membandingkan warna beras analog yang dihasilkan dengan tabel warna flat design color chart. Dapat dilihat pada Gambar 6 bahwa warna yang dihasilkan cenderung sama yakni berwarna cokelat. Nilai R, G, B didapatkan dari nilai R,G,B yang ada pada setiap kotak warna pada tabel warna flat design color chart. Rerata nilai R, G, B yang didapatkan dari beras analog berbahan baku tepung singkong yang diperkaya dengan daging ikan lele yang ditambahkan aroma vanili tidak berbeda nyata pada setiap perlakuan maupun pada perlakuan kontrol tanpa penambahan aroma vanili, seperti yang dapat dilihat pada Gambar 5 .

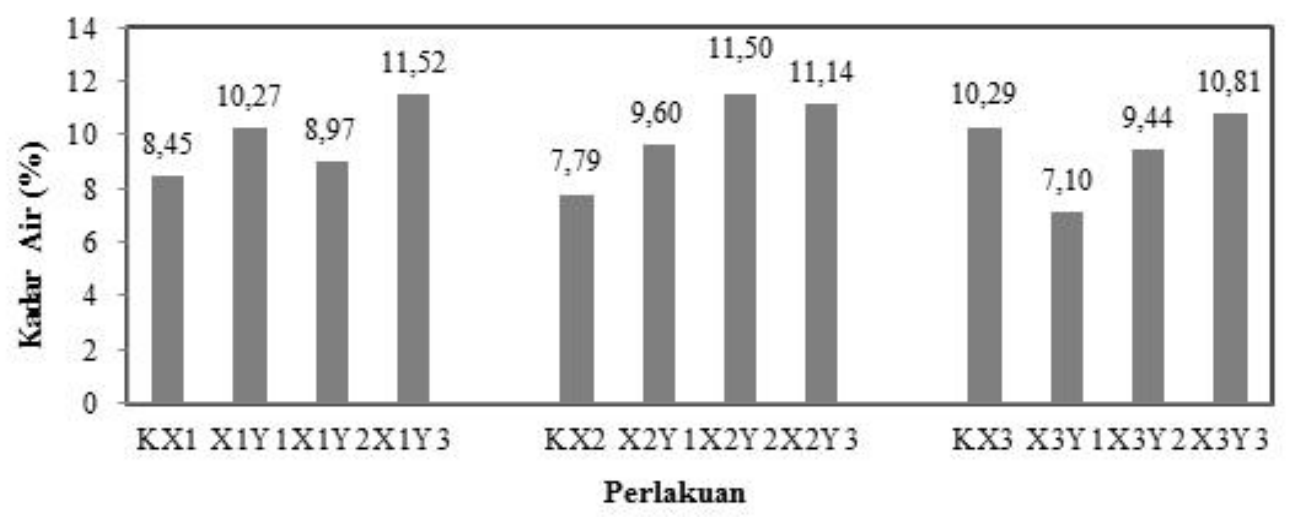

Gambar 4. Kadar air pada masing-masing perlakuan

Keterangan: $\mathrm{K}=$ Kontrol; $\mathrm{X} 1=5 \%$ tepung ikan lele; $\mathrm{X} 2=7,5 \%$ tepung ikan lele; $\mathrm{X} 3=$ $10 \%$ tepung ikan lele; $\mathrm{Y} 1=5 \mathrm{~g}$ vanili; $\mathrm{Y} 2$ = $7 \mathrm{~g}$ vanili; $\mathrm{Y} 3=10 \mathrm{~g}$ vanili

Tabel 4. Analisis sidik ragam terhadap kadar air

\begin{tabular}{lrrrrr}
\hline $\begin{array}{l}\text { Sumber } \\
\text { Keragaman }\end{array}$ & $\begin{array}{l}\text { Dearajat } \\
\text { Bebas }\end{array}$ & Tipe I SS & $\begin{array}{l}\text { Jumlah } \\
\text { Kuadrat }\end{array}$ & Nilai F & Pr $>$ F \\
\hline Tepung ikan lele & 2 & 8.372 & 4.186 & 0.87 & 0.45 \\
Vanili bubuk & 2 & 14.1 & 7.051 & 1.47 & 0.28 \\
Interaksi & 4 & 10.51 & 2.628 & 0.55 & 0.705
\end{tabular}

Ket : Jika nilai $\mathrm{Pr}>\mathrm{F}$ lebih besar dari alpha $=0.05$ maka perlakuan tidak, berpengaruh, sebaliknya jika nilai $\operatorname{Pr}<$ F lebih kecil dari alpha $=0.05$ maka perlakuan berpengaruh.

Berdasarkan analisis sidik ragam alpha $>0.05$, dalam pembuatan beras analog perlakuan penambahan aroma vanili dan tepung ikan lele tidak berpengaruh terhadap kadar air yang dihasilkan dapat dilihat pada Tabel 4 , sehingga tidak perlu dilakukan uji lanjut duncan. Hal ini diduga interaksi antara lama pengukusan dan lama penjemuran beras analog berpengaruh tehadap kadar air dari beras analog.

\subsection{Uji Sensorik}

Menurut panelis karakteristik nasi beras analog pada perlakuan X1Y3 diperkaya tepung ikan lele yang ditambahkan aroma vanili pada pembuatan beras analog dapat diterima dibandingkan perlakuan beras analog lainnya. Presentase tertinggi $70 \%$ yakni kategori agak suka terdapat pada perlakuan X1Y3 dengan tidak suka 
Pengaruh penambahan aroma vanili... (Junarli, Tamrin, dan Siti S)

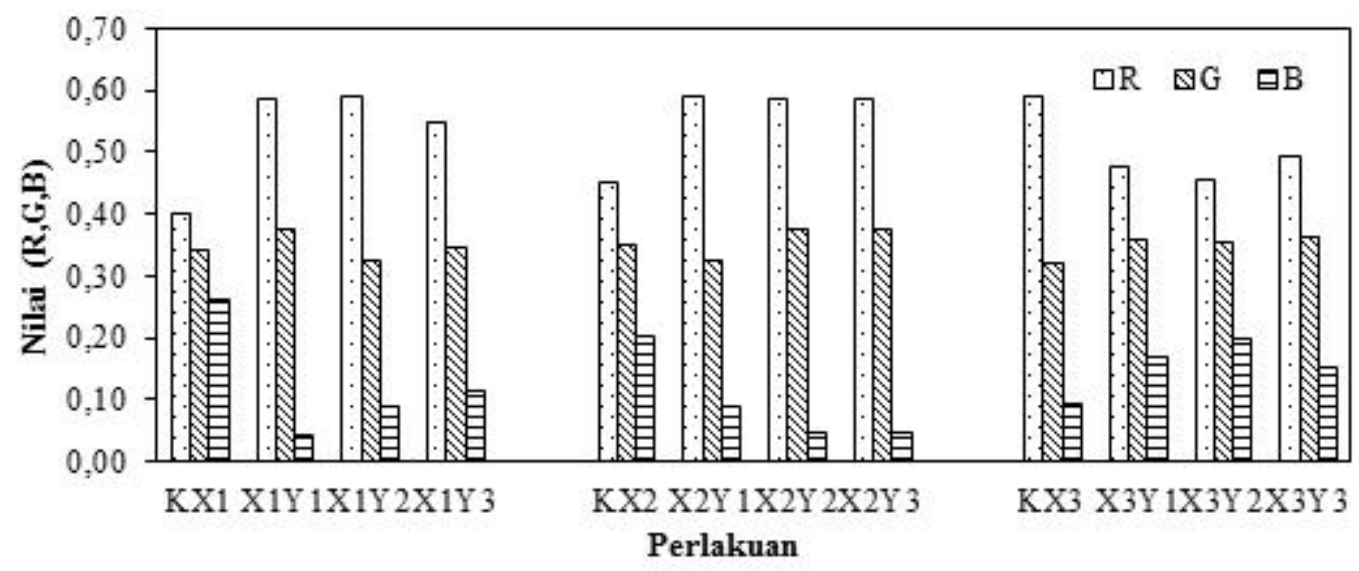

Gambar 5. Grafik nilai R, G, B pada beras analog

Keterangan: $\mathrm{K}=$ Kontrol; $\mathrm{X} 1=5 \%$ tepung ikan lele; $\mathrm{X} 2=7,5 \%$ tepung ikan lele; $\mathrm{X} 3=10 \%$ tepung ikan lele; $\mathrm{Y} 1=5 \mathrm{~g}$ vanili; $\mathrm{Y} 2=7 \mathrm{~g}$ vanili; $\mathrm{Y} 3=10 \mathrm{~g}$ vanili

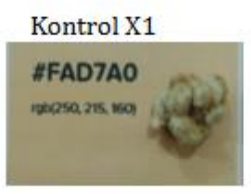

$\mathrm{X} 1 \mathrm{Y} 1 \mathrm{U} 1$

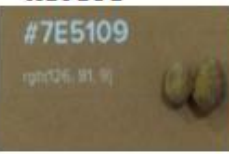

$\mathrm{X} 1 \mathrm{Y} 2 \mathrm{U} 1$

\section{\#7E5109}

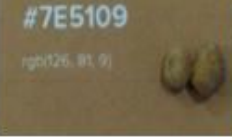

X1Y3U1

$=784212$

$\sin 2$
$\mathrm{X} 1 \mathrm{Y} 1 \mathrm{U} 2$

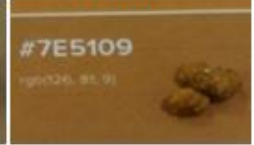

$\mathrm{X} 1 \mathrm{Y} 2 \mathrm{U} 2$

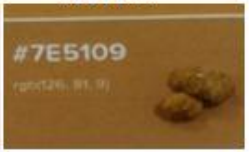

$\mathrm{X} 1 \mathrm{Y} 3 \mathrm{U} 2$

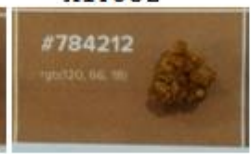

Kontrol X2

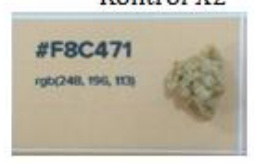

X2Y1U1

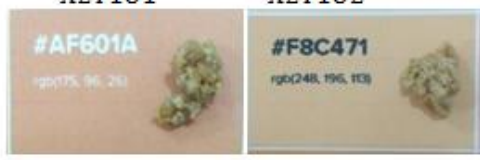

$\mathrm{X} 2 \mathrm{Y} 2 \mathrm{U} 1$

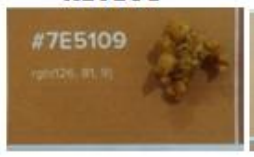

X2Y3U1
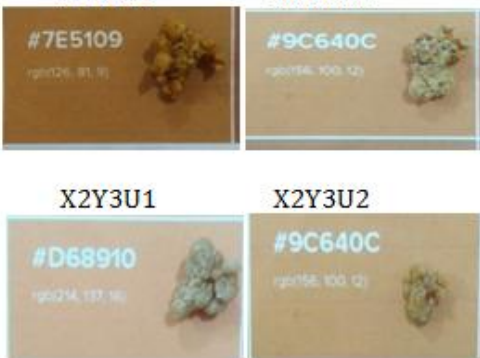

Kontrol X3

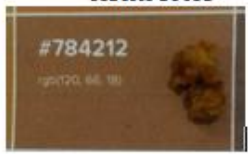

X3Y1U1

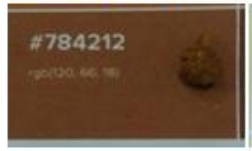

$\mathrm{X} 3 \mathrm{Y} 2 \mathrm{U} 1$

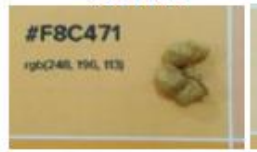

X3Y3U1

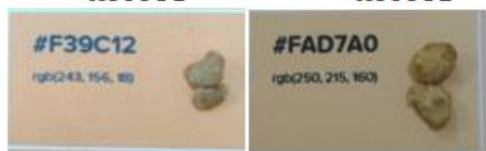

Gambar 6. Warna beras analog setelah penjemuran

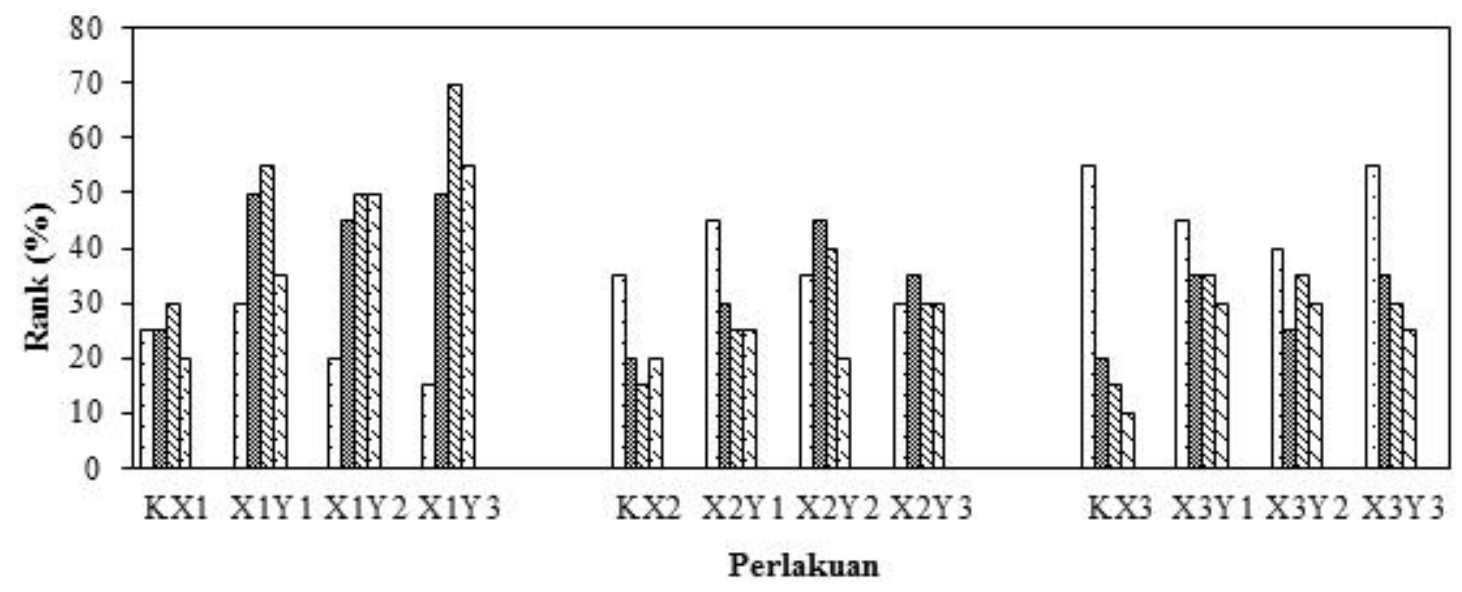

口TIDAKSUKA

Gambar 7. Uji organoleptik terhadap penerimaan keseluruhan 
sebanyak $15 \%$. Perlakuan X1Y3 konsentrasi tepung ikan lele lebih sedikit yaitu sebanyak $5 \%$ ditambahkan dalam pembuatan beras analog dengan bubuk vanili lebih banyak yakni $10 \mathrm{~g}$. Penambahan aroma vanili sangat berpengaruh pada tingkat penerimaan keseluruhan panelis terhadap beras analog, dilihat pada perlakuan kontrol KX3 tanpa penambahan aroma vanili dan perlakuan X3Y3 yakni penambahan tepung ikan lele lebih banyak dengan penambahan aroma vanili lebih sedikit. Presentase penerimaan panelis mencapai 55\% dengan kategori tidak suka.

\section{KESIMPULAN DAN SARAN}

\subsection{Kesimpulan}

1. Beras analog yang dihasilkan memiliki karakteristik: densitas berkisar 0,63 \% - 0,71 $\%$, daya serap $85,2 \%-107,4 \%$, kekerasan 7,01 - 9,19, dan kadar air 7,10 \% - 11,52\%.

2. Penambahan aroma vanili pada pembuatan beras analog berbahan baku tepung ubi kayu yang diperkaya dengan protein ikan lele tidak berpengaruh terhadap karakteristuk beras analog pada tingkat kepercayaan $95 \%$.

3. Hasil uji sensorik menyatakan bahwa beras analog yang paling disukai panelis adalah beras dengan penambahan tepung ikan lele $5 \%$ dan vanili $10 \mathrm{gr} / \mathrm{kg}$.

\subsection{Saran}

Saran yang dapat diajukan dalam penelitian selanjutnya adalah dilakukan pengujian umur simpan untuk mengetahui lama umur simpan dari beras analog agar dapat diaplikasikan ke masyarakat.

\section{DAFTAR PUSTAKA}

Dewi S.K. 2008. Pembuatan produk nasi instan berbasis Fermented Cassava $\quad \mathrm{F}$ l o u r Sebagai Bahan Pangan Alternatif.Skripsi Fakultas Teknologi Pertanian IPB.

Fitriyanto, M., S.R. Putra. 2013. Karakterisasi Beras Buatan(Artificial Rice) dari Campuran Tepung Sagu (Metroxylon sp.) dan Tepung Kacang Hijau. J u r n a l Sains dan Seni Pomits Vol. 2, No. 1, Hal 1-3.
Franciska, S.Y., Tamrin, S.waluyo, dan Warji. 2015. Pembuatan Dan Uji Karakteristik Fisik Beras Analog Dengan Bahan Baku Tepung Cassava yang Diperkaya Dengan Protein Ikan Tuna. Artikel Ilmiah Teknik Pertanian Lampung: 39- 44.

Kosasih, D., 2015. Diversifikasi Pangan Untuk Menekan Ketergantungan

Beras.Greeners.co.http:// www.greeners.co/berita/diversifikasipangan-untuk menekanketergantungan-beras/ (Diakses tgl 12 Oktober 2017).

Prabawati, S., N. Richana, dan Suismono. 2011. Inovasi Pengolahan Singkong Meningkatkan Pendapatan Dan Diversivikasi Pangan. Tabloid Sinar Tani Edisi 4-10 mei 2011 No. 3404 Tahun XLI.

Widowati, S. 2009. Tepung Aneka Umbi Sebuah Solusi Ketahanan Pangan. Balai Besar Penelitian dan Pasca Panen Pertanian. 
Pengaruh penambahan aroma vanili... (Junarli, Tamrin, dan Siti S) 